\title{
Demographic factor of intensification of innovation activity of Russian regions
}

\author{
Ekaterina Kovanova ${ }^{1, *}$, Nogan Badmaeva ${ }^{2}$, and SayanAlekseev ${ }^{3}$ \\ ${ }^{1}$ B. B. Gorodovikov Kalmyk State University, 358000, Pushkin st., 11, Elista, Russia \\ ${ }^{2}$ Kalmyk Scientific Center of the RAS, 358000, Ilishkinast., 8, Elista, Russia \\ ${ }^{3}$ East Siberian State University of Technology and Management, 670013, Klyuchevskayast., 40V, \\ building 1, Ulan-Ude, Russia
}

\begin{abstract}
The article presents an analysis of the influence of demographic factors on the development of innovations in the regions of Russia. The relevance of the study is associated with the fact that the Russian economy is distinguished by the presence of a large number of various problems that impede the rapid activation of innovative mechanisms. Not every region has opportunities for an innovative breakthrough. The purpose of the article is to compare the Russian regions (Kalmykia, Buryatia) in terms of the characteristics of the main demographic processes and their influence on the innovative development of regions. The article analyzes the following demographic indicators: population size, birth and death rates, age structure, working-age population, etc. The main research methods are the comparative method, analysis of statistical information. Analysis of the data presented showed that complex demographic processes are taking place in the republics. High migration outflow of the population, high mortality rate, a decrease in the share of the working-age population, migration of the rural population - all this affects the demographic potential of the region and, accordingly, the indicators of innovation development.
\end{abstract}

\section{Introduction}

The main task of modern socio-economic development of any country is to bring it to an innovative trajectory. Innovations introduced in new products, technologies, equipment, services are the most important factor in competitiveness in all economically developed countries. Russia is inferior to many countries in terms of innovative development. In the Global Innovation Index 2020, Russia is ranked 47th, down one point from last year. For Russia in this situation, the stake on innovation and the knowledge economy is an uncontested scenario of social development. Despite the fact that the regional diversity of the country opens up great opportunities for the implementation of promising innovative strategies in every constituent entity of the country, however, not every region has opportunities for an innovative breakthrough.

\footnotetext{
*Corresponding author: ekovanova@yandex.ru
} 
The problems of innovative development of Russia and its regions are highlighted in the works of both individual and in the works of many research groups. Azat Faskhutdinov note that the Russian economy is distinguished by the presence of a large number of various problems that impede the rapid activation of innovative mechanisms. A characteristic feature of Russia's economic development, in her opinion, is the interconnection of internal problems with global world challenges [1]. Socio-economic differentiation of regions significantly affects the innovative development of Russian regions [2-4]

Studies by Zemtsov, Muradov, et al. Show that the innovation market in Russia is underdeveloped, their financing is ineffective, and the quality of registered inventions remains low. They see a way out of this situation in the formation of an environment favorable for the development of innovative entrepreneurship. In their opinion, it is necessary to create attractive conditions for private, including venture, investments in innovative development and the development of the intellectual property market. As foreign experience shows, it is these factors that create a favorable climate for the development of innovations at the national level [5]. A number of researchers note the importance of creating special economic zones, industrial parks, introducing innovations in industrial clusters, digitalizing the national economy [6-9].

Irina Golova sees the reason for the weakening of the innovative competitiveness of Russian regions in the absence in modern Russia of politically significant influence groups, whose economic interests would be closely linked to the development of mechanical engineering, high technologies and the restoration of a full-fledged production structure [10]. Thus, we can conclude about the importance and urgency of the problem under consideration.

\section{Problem Statement}

The emergence of an innovative type of economy presupposes "the transformation of the intellect, the creative potential of a person into a leading factor in economic growth and national competitiveness." It is for this reason that the formation of an innovative type of economy at any level is determined, first of all, by the demographic potential of the territory, as well as the effectiveness of the organizational and economic mechanisms of its implementation [11]. Note that studies are used to build models of demographic factors for the development of innovations. [12]. In this regard, let us consider whether the features of the demographic processes occurring in them affect the innovation potential of the regions.

Demographic processes play a key role in the development of economic and social processes. The quantity and quality of the country's population determine its position in the world political and economic arena, the potential for economic growth, the change in technological structures, the possibility of developing innovations. Over the past 20 years, Russia has experienced significant political and economic changes. Demographic processes deserve attention, as there are negative trends in fertility and mortality rates.

The innovative activity in the region is positively influenced by the quality of human capital, expressed through the share of employed with higher education. People who graduated from the university, that is, acquired knowledge sufficient to develop new technologies, demonstrate a great tendency to create innovations [5].

The problem of the influence of demographic factors has been considered in a number of studies. I.E. Nikulina, I.V. Khomenko analyze the relationship of economic and innovative development of regions with ongoing demographic processes [13]. Other researchers identify two main factors affecting innovative development. This is, first of all, the share of the working-age population and the level of education of the population. They note that innovative development in the regions «is faced with the need to overcome the factors of insufficient education, conservative thinking, demographic decline, lack of 
attitudes, behaviors that contribute to the spread of innovations in the economy and public life» [14]. Nail Gabdullin, Damir Vakhitov, Aidar Zamaletdinov, Tatiana Kondratyeva analyzed the dynamics of the number of personnel engaged in research and development to assess the innovative potential of the regions [15].

\section{Research Questions}

Let's consider the influence of demographic processes on the innovation potential of regions using the example of two republics: Kalmykia and Buryatia. Despite the fact that the republics are geographically distant from each other, however, they retain deep spiritual ties, profess one religion. To date, a lot of research has been carried out to study the historical, cultural, and religious heritage of these ethnically close peoples of Russia, while comparative studies of modern economic, social, demographic processes in these regions are quite small.

It should be noted that the republics are in a difficult social and economic situation. According to the rating of the socio-economic situation of the regions in 2019, Buryatia and Kalmykia take the 69th and 79th place, respectively. The republics have one of the highest unemployment rates in the country (Republic of Buryatia - 74th place, Republic of Kalmykia - 75th place). Also, in terms of quality of life, Buryatia and Kalmykia occupy, respectively, 77th and 81st place among the subjects of the Russian Federation.

Let's consider the place of the regions we are considering in the rating of innovative development. The rating of innovative development is the result of ranking the constituent entities of the Russian Federation in descending order of the values of the Russian regional innovation index for 2017. The regions are divided into four groups based on the lag of the values of the integral indicator from the result of the leading region.

Table 1. Rank Kalmykia and Buryatia of the Russian regional innovation index

\begin{tabular}{|l|c|c|c|}
\hline Region & Ratinggroup & Rankbyrating & Index \\
\hline $\begin{array}{l}\text { Republic of } \\
\text { Buryatia }\end{array}$ & II & 43 & 0.3298 \\
\hline $\begin{array}{l}\text { Republic of } \\
\text { Kalmykia }\end{array}$ & IV & 80 & 0.2106 \\
\hline
\end{tabular}

The Republic of Kalmykia ranks 80th in the ranking of the constituent entities of the Russian Federation according to the value of the Russian regional innovation index: 2017. The Republic of Buryatia is in the middle of the rating and takes 43rd place, it is included in the second group of the Russian regional innovation index (Table 1).

\section{Purpose of the Study}

The subject of study in this article is the influence of the main demographic indicators in the regions under consideration (population size, fertility and mortality rates, age structure, able-bodied population) on innovative development in them.

This article aims to compare Russian regions (Kalmykia, Buryatia) in terms of the characteristics of the main demographic processes and their impact on the innovative development of regions.

\section{Research Methods}


The main research methods are the comparative method, the analysis of statistical information. A comparative approach is applied, namely, a comparative characteristic is carried out for a number of demographic indicators of the regions we study - the Republic of Buryatia and the Republic of Kalmykia. Comparative analysis is often used when comparing complex objects and phenomena that are described by a set of widely varying features; therefore, this method is well suited for regional studies.

\section{Findings}

The population of the Republic of Kalmykia as of January 1, 2019 was 272.65 thousand people, Buryatia - 983.27 thousand people. In terms of population, Kalmykia ranks 72nd among all constituent entities of the Russian Federation, Buryatia - 24th. Analysis of population changes from 2003 to 2017 shows that in the Republic of Buryatia there is an increase in the population, in Kalmykia - a decrease in the size of the population. A slight increase in the population of Buryatia has been noted since the 2000s. Until 1999, the population in Buryatia was declining. In 1989, the population of Buryatia was 1038.2 thousand people, in 2002 - 981.2 thousand people, in 2010 - already 972.0 thousand people. It should also be noted that in the republics a significant proportion is made up of the rural population: in Buryatia more than $40 \%$, in Kalmykia - more than $54 \%$ (The proportion of urban and rural population, Regions of Russia, 2018). At the same time, there is a tendency for a decrease in the number of the rural population, both in Kalmykia and in Buryatia. The considered republics have a high migration outflow of the population. Researchers of migration processes note that population migration occurs against the background of complex socio-economic processes in the republic, unemployment, especially in rural areas.

In Buryatia, the gender disproportion is most pronounced: there are an average of 1100 women per 1000 men, and 1082 women in Kalmykia. According to Rosstat, this proportion is typical for almost all regions of Russia.

In terms of total fertility rates (number of births per 1000 people), Buryatia is one of the ten regions with a high fertility rate. In 2018, the total fertility rate in Buryatia was 2.04, while the all-Russian indicator in 2018 was 1.58 . In Kalmykia, the birth rate was 1.6. In 2017, Kalmykia ranked 46th in terms of fertility in the country.

Table 2. Population growth in Kalmykia and Buryatia for 2016-2018

\begin{tabular}{|l|c|c|c|}
\hline \multicolumn{1}{|c|}{ Region } & Growth & Naturalgrowth & Migrationgain \\
\hline RepublicofKalmykia & -2.21 & 1.41 & -7.52 \\
\hline RepublicofBuryatia & 0.10 & 12.48 & -11.21 \\
\hline
\end{tabular}

The highest mortality rates in Russia, including Kalmykia and Buryatia, were in 2005. Among all regions of the Russian Federation, Buryatia ranked 70th in this indicator in 2017 (mortality rate 10.7), Kalmykia - 72nd place (mortality rate 9.9 ).

One of the main problems of demographic development is the mortality rate of the working age population. The number of deaths in 14 in Kalmykia was 405.5 per 100 thousand people, in Buryatia - 546.2.

Thus, in Buryatia, the mortality rate of the working-age population is higher than in Kalmykia. It is important to note that life expectancy in Buryatia is also lower than in Kalmykia and amounted to 70.69 and 73.54 years, respectively, in 2017. At the same time, in Kalmykia, the low rate of natural population growth does not overlap the migration decline.

Table 3. Birth and death rates in 2018 


\begin{tabular}{|l|c|c|}
\hline Region / Country & Birth rate & Mortality rate \\
\hline RepublicofKalmykia & 11.1 & 9.7 \\
\hline RepublicofBuryatia & 14.1 & 10.7 \\
\hline Russian Federation & 10.9 & 12.5 \\
\hline
\end{tabular}

According to the data presented in the table, it can be seen that the birth rates in Kalmykia and Buryatia are higher than the average Russian indicator (tabl. 3). At the same time, mortality rates in these republics are lower than in Russia as a whole.

Demographic indicators are one of the main characteristics of the reproduction of labor resources in the republics under consideration. Since 2005, the number of labor resources in Kalmykia and Buryatia has been decreasing. On average, from 2005 to 2018, the share of the working-age population in Kalmykia decreased by $9.1 \%$, in Buryatia - by $9.6 \%$. At the same time, the population over the working age is increasing: from $14.4 \%$ to $23 \%$ - in Kalmykia, from $15 \%$ to $20.6 \%$ - in Buryatia (tabl. 4, 5)

Table 4. Age composition of the population in the republics in 2018

\begin{tabular}{|l|c|c|c|}
\hline Region & $\begin{array}{c}\text { Population younger } \\
\text { than working age }\end{array}$ & Populationofworkingage & Populationoverworkingage \\
\hline RepublicofKalmykia & 21.9 & 55.1 & 23.0 \\
\hline RepublicofBuryatia & 24.6 & 54.8 & 20.6 \\
\hline
\end{tabular}

Table 5. Change in the share of the working-age population in the republics from 2005 to 2018

\begin{tabular}{|l|c|c|c|c|c|c|}
\hline Region & $\mathbf{2 0 0 5}$ & $\mathbf{2 0 1 0}$ & $\mathbf{2 0 1 2}$ & $\mathbf{2 0 1 4}$ & $\mathbf{2 0 1 6}$ & $\mathbf{2 0 1 8}$ \\
\hline RepublicofKalmykia & 64.2 & 63.4 & 61.3 & 59.1 & 56.9 & 55.1 \\
\hline RepublicofBuryatia & 64.4 & 61.9 & 60.0 & 58 & 56.1 & 54.8 \\
\hline
\end{tabular}

The analysis of the data in the table showed that in the republics the share of the population of working age is decreasing, and the share of the population over the working age is correspondingly increasing. It should be noted that in Kalmykia the proportion of the population over the working age is higher than in Buryatia. At the same time, the share of the population under working age in Kalmykia is lower than in Buryatia. Decrease in the population of working age, i.e. the most economically active part of the population began in the late 90 s. In the short term, this process will grow, which may cause a shortage of labor in the labor market. Based on the current situation, it is most likely that in the near future, changes in the age composition of the population will be unfavorable. The rate of decline in the population of working age will increase, and the process of demographic aging of the population will intensify.

This process negatively affects the socio-economic development of the regions. In this regard, the task of effectively using the already formed labor potential, increasing the level of its employment at the present time and in the future becomes urgent.

\section{Conclusion}

Analysis of the data presented showed that complex demographic processes are taking place in the republics. High migration outflow of the population, high mortality rate, a 
decrease in the share of the working-age population, migration of the rural population - all this affects the demographic potential of the region and, accordingly, the indicators of innovation development. The working-age population with higher education has a high migration mobility, and young people who received education in other regions do not return to the regions.

The most difficult situation is in the Republic of Kalmykia. The problem of migration of rural youth is especially relevant for the republic, where the agricultural sector is key in the economy. Due to the active departure of young rural residents, the agricultural sector may be left without workers, and subsequently this trend will intensify. Solving the problems of creating the necessary conditions for the development of agricultural production is associated with the availability of labor resources, the composition and dynamics of which directly depend on the demographic situation in the region. At the same time, in modern realities, it is necessary to find innovative ways of developing the agro-industrial complex, which will contribute to the growth of the efficiency of agricultural production and, as a result, the reproduction of the labor potential of the agrarian region.

The Republic of Buryatia is in the middle of the rating of innovative development of Russian regions, however, the current migration situation and the reduction in the share of the working-age population significantly affects the development of the republic. In our opinion, the republic does not fully use the human potential of the region.

The article was prepared within the framework of the project «Socio-economic trajectories of development of Mongolian-speaking regions of Russia (on the example of the republics of Kalmykia and Buryatia)» (RFBR grant 19-010-01082).

\section{References}

1. A. Faskhutdinov, Procedia - Social and Behavioral Sciences, 210, 188-192 (2015)

2. G. Litvintseva, E. Stukalenko, Procedia Economics and Finance, 16, 56-63 (2014) doi: 10.1016/S2212-5671(14)00774-6

3. M. El-Shagi, J. Fidrmuc, S. Yamarik, Economic Modelling, 91, 550-558 (2020) doi.org/10.1016/j.econmod.2019.11.003

4. V. Uzun, N. Shagaida, Z. Lerman, Land Use Policy, 83, 475-487 (2019) doi.org/10.1016/j.landusepol.2019.02.018

5. S. Zemtsov, A. Muradov, I. Wade, V. Barinova, Foresight and STI Governance, 10(2), 29-42 (2016) doi: 10.17323/1995-459X.2016.2.29.42

6. S. Sosnovskikh, Russian Journal of Economics, 3, 174-199 (2017)

7. E. Gromova, D. Timokhin, G. Popova, Procedia Computer Science, 169, 461-467 (2020)

8. I. Glebova, Y. Yasnitskaya, N. Maklakova, Procedia-Social and Behavioral Sciences, 191, 2374-2381 (2015) doi.org/10.1016/j.sbspro.2015.04.378

9. I. Ablaev, Procedia Economics and Finance, 24, 3-12 (2015) doi: 10.1016/S22125671(15)00605-X

10. I. Golova, Economy of region, 3, 294-311 (2015)

11. I. Glebova, S. Kotenkova, Procedia Economics and Finance, 14, 230-235 (2014)

12. J. B. Shukla, H. Kushwah, K. Agrawal, A. Shukla, Nonlinear Analysis: Real World Applications, 13-1, 186-196 (2012) doi.org/10.1016/j.nonrwa.2011.07.024

13. I. E. Nikulina, I. V. Khomenko, Procedia - Social and Behavioral Sciences, 166, 142$146,(2015)$ 
14. A. Mikhaylova, A. Mikhaylov, O. Savchina, Data in Brief, 27, (2019) doi.org/10.1016/j.dib.2019.104640

15. N. Gabdullin, D. Vakhitov, A. Zamaletdinov, T. Kondratyeva, Procedia Economics and Finance, 24, 237-245 (2015) 